\title{
The Dutch Situation: An Ever Continuing Story
}

\author{
Bert Zwaneveld $^{1}$ and Victor Schmidt ${ }^{2}$ \\ ${ }^{1}$ Open Universiteit (Open University), Heerlen, The Netherlands \\ ${ }^{2}$ SLO, Nationaal Expertisecentrum voor Leerplanontwikkeling \\ (Netherlands Institute for Curriculum Development), Enschede, The Netherlands \\ g.zwaneveld@uu.nl, v.schmidteslo.nl
}

\begin{abstract}
In this chapter we describe the development of teaching with and about computers, mainly in Dutch secondary education. The focus is on the years $1970-1995$, but we also give some insight into what happens afterwards. Because there are only a few written sources available of what happened in classrooms, we give most attention to national policies during that period. With the help of some colleagues from teacher training institutions we can also present some insight in what support was offered to their students and to teachers who were already in duty. We also report about the resources for teaching: courses, the teachers' association, an advisory institution, books/periodicals and software/courseware. In our conclusions we mention, that initially there was no difference between teaching with or about computers. The most interesting point in the conclusions is that the government rather lately developed a policy and thought that that policy would be sufficient for future development of teaching with and about IT in schools. This assumption turned out to be false and each time, up to nowadays, the government had to take its responsibility on these issues.
\end{abstract}

Keywords: teaching with and about computers, Dutch national policy on the use of computers in education, teachers' resources.

\section{Introduction}

In general terms, the development of the use of IT in education took the following course. At the end of the 1960s and beginning of the 1970s, computers were first introduced here and there in education, especially secondary education. At that time, computers could hardly do anything compared to today. Given their limited possibilities, there was no field of IT. There was only informatics, primarily involving the teacher programming a computer in BASIC or even machine language, and then teaching the steps to his or her pupils. The computer could hardly be used for teaching purposes. During the 1980s the government started getting involved, and national projects were set up to stimulate education with and about computers. But there was still little difference between what we now call IT and informatics. Only after the first National Informatics Education Congress in 1990 in Maastricht (NIOC1990) can we finally say with some reservations that IT and informatics begin to occupy a regular 
place in the Dutch educational system. From that moment on the use of IT in education and teaching in the school subject of informatics started to diverge, although it would take until 1998 for the government to introduce informatics as a school subject in secondary education.

We shall employ the following terminology. Learning or teaching with the computer means education in school subjects where the computer is used in some way as a teaching tool. By learning or teaching about the computer, we mean education in what is called informatics in Dutch and computer science in English; it covers topics like programming, databases, operating systems, system development, etc. We shall use the term 'informatics' here. There are also the basic computer skills, like how to use a word-processing programme, a calculation programme, a presentation programme, use of the computer's storage options and nowadays the internet. In the Dutch educational system, the terms 'civil informatics' and later on 'IT studies of computer and information literacy' or 'information science' are used to designate those topics.

This chapter starts with a few stories in section 2 about people who came into contact with computers at school as teachers or pupils in the last century. We want to give the reader a first impression of what was going on in the classroom in those days. In section 3 we follow the developments up to the specified NIOC1990 and at the end summarise how it went on from there. In section 4, NIOC1990 is described in detail. We wrap up, in section 5, with several conclusions and suggestions for the future regarding learning with and about computers.

\section{A Few Stories}

During the National Informatics Education Congress of 2013 (NIOC2013), there was a session in which informatics teachers from different educational sectors talked about their experiences with computers in the teaching that they received or gave. Some of those stories are given below as a warm-up for this chapter.

The participants sharing their experiences had different backgrounds: pupil, teacher, researcher. The experiences are arranged here according to type of school. They are written from a personal perspective, referring to one of the storytellers. Although there are quotation marks, the citations are not literal.

\subsection{Primary Education}

"In the years 1994-2002 our primary school did nothing with computers until my father's company replaced its old computers and gave a large number of them to our school. The computers were primarily used to teach typing, however. The pupils prepared assignments with them. They also learned to search on the internet to research the assignment projects. I learned a bit of HTML with my father's help. The school offered these activities in group 7 and group 8 "l

\footnotetext{
${ }^{1}$ This is the end of primary school with pupils aged 10 to 12 years old.
} 
"I think the most important explanation for why our school did this was that it could see the importance of doing so. But as a public school there was no founding available. How important this was considered is reflected in the fact that once the computers were there, they were quickly linked together in a network. Some software was available, which had been an appendix in the form of a CD enclosed with a magazine or a book, but this was not used in the class. The children could buy it for use at home.

"It was striking that many children did not start working behind the computer, but primarily sat around causing trouble. There was too little supervision, if any."

\subsection{Secondary Education}

"During my doctoral research into teaching modelling in physics, at the start of the $21^{\text {st }}$ century, I saw the same phenomenon, pupils sat around causing trouble more than they used the computer as a learning aid.

"My research concerned the attitude of pupils to IT, more in general with regard to science and technology and the role of modelling. The software used was PowerSim, and the activities took place in the senior high school (A-level building) for havo and vwo ${ }^{2}$. The idea was to expose the pupils to the procedures used in physics at the university, including the computer to simulate physical processes. From chats with the pupils (which was possible), it seemed that the learning results were definitely reasonable. This applied especially to the pupils writing short and coherent chats. It also seemed that the attitude was closely related to the course of the learning process. The better that went, the greater the motivation and the attitude. The reasoning was better and the modelling skills improved."

"The subject informatics in secondary education at the end of the last century, at the start of the 1980s, was initially focussed on controlling the computer: working with MS-DOS. Programming has to be done at the assembler level. Assistance was provided by an IBM computer and the linked P2000-computers from Philips. Then with the development of the home computer, this training shifted to explaining about the computer and learning to programme it, especially in BASIC, sometimes even with an advanced version of it. The initial assignments were always based on mathematics. Later there were other assignments linked to other subjects, sometimes they were even subjects that were not taught at school. One example of this was the assignment to display the starry sky at night for a particular day on the screen.

\footnotetext{
${ }^{2}$ See appendix C.
} 
"This informatics course was only taken by boys. It was supervised by a range of teachers, but there were actually only two who were familiar with the subject. Pupils were quickly better than most of the supervisory teachers. The school did find this subject important. Only much later was the transition made from 'how the computer works' to 'what the computer can do', as is now the case."

"In the course mathematics II, top secondary school, that existed between 1973 and 1985, there was a series of optional modules, e.g. complex numbers. At my school I studied numerical mathematics, where the pupils had to programme and solve typical mathematical problems. The programming language was called ECOL, a derivative of Algol/Pascal. Examples of such assignments were: numerical integration, the course of the path over a cloverleaf, so that it closed as smoothly as possible, estimating the number of people watching a football game on TV on the basis of the change in pressure in the water supply. At the half-time break, it dropped because of toilets being used. The pupils had to put their programme on special cards. In a specially designed box they were sent to what is now called the Freudenthal Institute, and the output sent back a few days later. Of course, there were usually some error messages."

"At my school we learned to programme in Logo rather than a language like Pascal or BASIC.”

\subsection{Tertiary Education}

"In the 1990s Pascal was the standard language in the subject informatics. The language was the important thing, not what you could do with it."

\section{A Short History of the Use of Computers in Education in the Netherlands}

\subsection{Global View}

The use of computers in education was started by enthusiastic teachers during the period from the end of the 1960s to the beginning of the 1980s. There were hardly any female teachers involved. The starters thought, correctly in hindsight, that pupils from primary and secondary education should become familiar with computers at school, or even that working with computers could support and improve their learning. We could call these teachers 'early adopters'. The very first teachers were what we now would call 'computer nerds' or 'computer freaks'. They had access to a computer like the Tandy or the Commodore 64 that they had to programme themselves. 
In the early days, the pupils in the class did not yet work with them directly but could be demonstrated certain things. The programmes often concerned the domain of mathematics, but definitely not always. From the books which appeared in this period, often with the term 'computer science' in the title - we return to these books in section 3.5, Educational teachers' support - it appears that hardly any distinction was made between what we now call IT and informatics. This was not surprising given the level of the architecture and the capacity of those older computers. Basically, the computers could do nothing without being directed step by step by the user, here the teacher. As a result, many books emphasised directing the computer far more than encouraging the pupils only to work with the computer. But it is clear that definitely the authors of these books, and we can assume also the early adopters, did intend for groups of pupils to start working on the computer. Several of these books contain listings of usually BASIC programmes that had to be entered by the teacher. Examples of such programmes are given in Table 1 in appendix A (Docters van Leeuwen 1982, p. 249):

The use of computers in schools by the pupils took off with the arrival of small, but nevertheless quite powerful computers like the Acorn from BBC and the P2000 from Philips. This latter computer was introduced in 1981. Its core was a z80microprocessor. For both the Acorn and the P2000, the programmes and data had to be entered using a cassette tape. Wikipedia calls it a 'home computer'. The P2000 was primarily used in Dutch education because of its robust design. There was a special price for schools for this P2000 and the associated software.

Note. An outlier in the use of computers in education in this period was the possibility offered by the teaching and education computer centre of the University of Utrecht in the early 1980s. This centre was a predecessor of the current Freudenthal Institute. In the now defunct school subject of mathematics II in vwo which was intended for the better mathematics pupils who were expected to go on to study a scientific or technical programme at a university, the pupils had to choose a topic. If they chose computer mathematics, actually a form of numerical mathematics, they could put their programmes written in ECOL (a variation of Algol/Pascal) on special cards, which were sent by the teacher to the centre in Utrecht, and the result returned a few days later by post, usually with error messages. One of the stories in section 2 , Afew stories, is about this process.

In the early 1980 s, the introduction of the personal computer, quickly abbreviated in the Dutch vernacular to PC, with the operating system MS-DOS provided a push from the outside. In the wake of the arrival of the PC, numerous companies and institutions introduced so-called PC-home projects. These projects were meant to encourage employees and their families to work with the PC at home; it was generally agreed in the collective labour agreements that employees would receive compensation from their employer to purchase a PC. These PC-home projects certainly helped to encourage the use of the computer in schools. Through these PChome projects, pupils were given the opportunity to work with a computer at home. Schools had relatively limited resources to provide their pupils with computer access. 
Parents who recognised the importance of computers encouraged their children's schools to employ computers in education. In addition, they could make a contribution with the PC at home. It wasn't until 1983 that 100 schools for secondary education were enabled by the government to install eight computers per school. We shall return to this topic in section 3.2, National policy.

With the introduction of MS-DOS and the PC, the use of computers in the classroom became much easier. Along with the development of the internet in the 1990s, we have practically arrived at the current situation. Kennisnet, a knowledge centre subsidised by the government that is meant to assist schools with implementing IT in education, to issue recommendations and to conduct research, has been saying the same thing for years about the use of computers in Dutch education (Kennisnet 2013b, p. 52):

“... that schools are enthusiastically embracing IT. Over several years, the use of IT has consistently grown in all sectors of education. The use of IT is important to prepare pupils for future careers and their functioning as citizens in an IT-rich and digital society.

Scientific research supports the increasing proof that IT - with good, targeted and dosed use - contributes to the motivation, learning performance and reading speed of pupils. IT-applications support teachers with teaching and help the management to create a costeffective school organisation. IT offers possibilities in the field of administration, organisation, coordination and personnel matters."

But Kennisnet added as criticism (Kennisnet 2013b, p. 55):

"Despite the social necessity and the proven educational benefit of IT, it is still underused at many schools."

According to Kennisnet (2013a) this lack of use is associated with the unbalance between vision of teachers, school directors, school boards and parents, expertise of the teachers primarily, availability of digital content and applications, and the infrastructure at schools.

\subsection{National Policy}

Following on from Ten Brummelhuis and Plomp (1993, 1994), we distinguish three phases in the government's policy regarding the use of computers in education. In the government's jargon these phases are given a label (printed in italics). We add the name of the associated project. In the detailed discussion of each phase, various matters will be clarified.

- 1982-1984: exploration with the 100-schools project

- 1984-1989: basic provision and introduction with the Informatics Stimulation Plan project

- 1989-1992: consolidation with the OPSTAP project.

And we add in this chapter the subsequent period, 1992 and later, to complete the picture. 


\subsubsection{Exploration: 1982-1984}

In the 1970 s there was hardly any government policy on informatics and information technology. Around 1980 the government began to realise that it could not remain sitting on its hands. The country appeared to be lagging behind its neighbours, a conclusion that was contested ten years later by the Advisory Council for Education (Advisory Council for Education 1994). Former world chess master, Prof. Max Euwe, expressed the importance of computers in education in 1980 on the occasion of the opening of an exhibition on informatics to celebrate the 100-year anniversary of the Vrije Universiteit (Euwe 1980, p. 441) as follows (see also the booklet by R.P. van de Riet in Appendix B):

"In secondary education as well and ultimately even in primary education, room must be made for informatics, or computer science. Schools prepare pupils for society, and computers are becoming an important component of society. Especially as far as mysterious matters like automation and computers are concerned, it is important that people are informed.

Knowledge can allay the unfounded anxiety derived from the performance of machines that exceeds the limits of our imagination. Ignorance is a poor advisor, but is encountered everywhere, even in the highest intellectual circles. If a person becomes at least somewhat familiar with the phenomenon of computers from a young age, the anxiety will disappear and be replaced by understanding, with or without consent. It will allow any criticism to be supported by arguments, which can be discussed. People at least know what they are talking about, what they are protesting against."

In 1983 the two-year 100-schools project was initiated, in which participating schools for secondary education were each given 8 microcomputers with the aim to acquire two years of experience with education in 'civil informatics' - nowadays we would say the 'use of information technology (or IT)' - and in informatics. In a special edition of Euclides devoted to informatics, a monthly magazine for teaching mathematics and the organ of the Dutch Association of Mathematics Teachers, which appeared in October 1983, a series of articles reported how schools were employing the computers of the 100-schools project. It revealed that along with BASIC, LOGO was also being used as a programming language. A lot of attention was paid to what was taught in the citizen informatics lessons (see the next section). As could be expected, all the contributions were positive.

\subsubsection{Basic Provision and Introduction: 1984-1989}

In 1984 the government took a bigger step with the Informatics Stimulation Plan, abbreviated INSP, (Ministry of Education and Science, 1984). This stimulation plan aimed to support informatics and its application in education, research, the market sector and the government. Education was expected to: 
- familiarise citizens with the information technology. The term 'citizen informatics' was applied to this.

- create 'human capital' to strengthen the market sector, especially for vocational education.

To achieve these goals, a considerable sum (for its time) of NLG 267.5 million (= $€ 121.4$ million) was reserved for the period 1984 - 1988. It was meant to pay for the development of software (educational) and for providing training (refresher courses) on a large scale. For each of the education sectors, this was elaborated in the following points of attention (see appendix $\mathrm{C}$ for an overview of the education system in the Netherlands):

- Vocational education: use of information technology in vocational subjects

- General secondary education: development of a citizen informatics subject in the first phase and an informatics elective in the second phase.

- Use of the computer in all subjects.

- Development of computer-assisted teaching.

The use of computers in primary education had a low priority for the government in the Informatics Stimulation Plan.

One of the components of the Informatics Stimulation Plan in the period 19851988 was the NIVO project, which was conducted and partly financed by the government (Casimier 1988; Ten Brummelhuis \& Plomp 1993, 1994; Lepeltak 1997). NIVO stands for New Information Technology in Secondary Education. The aim of this project was to familiarise the pupils in all 2000 schools for secondary education

Table 1. Description of the software packages and courseware delivered to all secondary schools

\begin{tabular}{ll}
\hline Program & Description \\
\hline Software & \\
\hline PC-TYPE & Word processor for professional use \\
PC-FILE & Universal database management program \\
PC-CALC & Spreadsheet \\
PC-GRAPH & For creating bar graphs, pies, scatter grams, etc. \\
INSTRUCT & Individual training programs for the PC \\
TAIGA & Authoring system for development of CA1 programs \\
EGI & Program for free drawings \\
SUPERDRAFT & Simple version of CAD program \\
DOKA & Educational game for 'developing' an invisible text \\
DMS & Program for dynamic models: simulation \\
\hline Courseware (lesson ideas) \\
\hline PHYSICS & Examples of PC-CALC for six topics in physics \\
BIOEART & Applications of PC-CALC in biology and earth science \\
BIODMS & DMS application in biology (blood sugar and temperature) \\
MATH & Examples of PC-CALC application in mathematics \\
TAILANG & Examples of developing drill/practice CA1 for foreign \\
& languages with TAIGA \\
LANGDOK & Examples of how to use DOKA for foreign language exercises \\
\hline
\end{tabular}


with learning with the computer from the start, by integrating the use of computers in the school subjects. The 100-schools project was incorporated in the NIVO project. The schools were given 11 computers each in a network. They were advised to set aside a classroom devoted to this. The computers were supplied by three companies: Philips, IBM and Tulip, which also provided part of the budget. The schools were also given software: word-processing programmes like PC-Type and calculation programmes like PC-Calc. Table 1 lists all the programmes the schools were given.

An equally important element was the requirement that three teachers, including at least one without computer experience and at least one woman, had to take training courses. These courses were provided by the institutes training teachers for the lower secondary school. Casimir (1988) reported that the 90-hour course developed by her institute, and intended for teachers without any computer experience, consisted of the parts:

- Data and information

- Computers and society

- Applications

- Programmable machines

- System development (automation)

- Computers and education.

A considerable proportion of the available budget was intended for what was called 'learning with information technology': use of information technology in all subjects with an eye on vocational preparation and increasing the attractiveness of the subjects. The focus should shift from provision of the equipment to software development.

Evaluation by external experts of the INSP and of the NIVO project. At the start of the Informatics Stimulation Plan, De Bruijn (1984), at that time professor of mathematics at the Technical University of Eindhoven, published the following analysis and criticism of the plan in a periodical on information and information policy. We reproduce here the most striking aspects of his commentary.

In general, he was satisfied with this initiative of the government. The government simply could not ignore the arrival of the computer and its use in education.

De Bruijn considered the term 'citizen informatics' for education about computers rather unfortunate. He preferred the label: training to be a consumer in the information society. For education with computers he used the term 'computer-aided instruction'.

The fact that informatics was meant to be an elective in the second half of secondary school according to the Informatics Stimulation Plan De Bruijn considered a major error, because it would mean that no tertiary education course would require informatics as an entry requirement. It should be a mandatory subject throughout all the years of general secondary education. These two issues ensured, he felt, that the status of informatics would not be good. Not until 1998 did informatics become an elective in the last two years of academic secondary education.

The most important of De Bruijn's criticisms is that the objectives of the plans for secondary education had not been specified. Nowadays we would say that the longterm vision was lacking. The most important arguments centred around: the Netherlands is lagging behind its neighbours in this field. If computers were 
employed in education, this was more likely due to pressure exerted by companies and parents.

Lepeltak (1997) cited Tjeerd Plomp, advisor in the 1990s to the former Minister of Education on the subject of the use of computers in education, when he was reflecting on the NIVO project:

"If we look back, a few important elements are evident. To start with, we have ascertained that the idea prevalent in the early 1990s, that the Informatics Stimulation Plan activated an entire revolution, was only partly correct. Computers are now indispensable for schools. The subject of information science has a firm position in secondary education, and especially in vocational education. It has also acquired a set place in some general school subjects. For example, in physics, informatics forms part of the examination requirements. Unfortunately, there is stagnation in its use in everyday lessons; the enrichment of daily teaching by using IT. People realise now that what the ministry anticipated in the early 1990s has not come to pass."

\subsubsection{Consolidation: 1989-1992}

After expiration of the subsidy period of the Informatics Stimulation Plan, schools were supposed to be able to find sufficient funding for the integration and consolidation of information technology in their education. In 1989 however a second government initiative followed instead, with the aim of expanding the attainments from the 1980s. It was given the name OPSTAP (Ministry of Education, Culture and Science 1988). This umbrella covered a wide range of projects. In secondary education an education innovation project started under the name PRINT (stands for Project Introducing New Technologies). The NaBont project was specifically oriented to vocational education. This abbreviation stands for Vocational Education Training in New Technologies. NaBont focussed on more than the use of computers, it covered all new technologies in general. And a spotlight was turned on primary education. Primary schools had obtained computers using their own funds in the second half of the 1980s (1985: 10\% - 1989: 50\%; 1 computer per 89 pupils) (Ten Brummelhuis \& Plomp 1994). Under the umbrella of OPSTAP, the Comenius project was initiated, which made standardised equipment with software available for every primary school. In 1994 the delivery of the Comenius equipment was completed. Secondary schools were in the meantime amply supplied with an average of 21 computers per school, and most of them had one or more dedicated computer rooms (Ten Brummelhuis \& Plomp 1994).

Primary schools used their Comenius equipment extensively after some initial hesitation. Half of the teachers at schools that received the equipment in 1990 were using it weekly in their lessons three years later (Ten Brummelhuis \& Plomp 1994). The use of computers in secondary education was disappointing in comparison. Only in the lessons on information science - the new name for citizen informatics - were computers used because of the nature of the subject. At that time, only $3 \%$ of the teachers used the computer more than 1 hour per week (Ten Brummelhuis \& Plomp 1994). 


\subsubsection{And Further: $1992-\ldots$}

We should now turn our attention to the first National Informatics Education Congress of 1990, abbreviated NIOC1990, which we consider a turning point in the development of education with and about computers in the Netherlands. We feel, however, that it deserves its own section in this story: section 4, NIOC1990: a turning point. We describe in this section what happened further in the 1990s.

The government's efforts seemed more or less to be finished in 1992. In the policy memorandum 'Enter, the future', it was concluded that schools were now capable of integrating and consolidating information technology in their education. In 1997 which we realise is over the limit of the early 1990s - the government came to the conclusion that new investments must be made in the use of IT in education: the action plan 'Investing in Progress' (1997; see also Lepeltak 1997). The Advisory Council for Education, the highest advisory body of the Minister of Education, noted the following in a recommendation on this action plan (Advisory Council for Education 1998):

"The Council greeted with approval the ambitious action plan 'Investing in Progress'. The high priority it assigned to the use of IT in education was supported by the Council. Points of concern for the Council were the didactic foundation, the uncertainty about the next steps to take, and the financial framework. The Council felt that the action plan put too much emphasis on providing the material conditions and paid too little attention to the educational aspects of IT use. The use of IT in education should primarily be based, according to the Council, on considerations of substance: what should be done with IT, why was this necessary, and how should it be accomplished? Furthermore, the action plan stressed a mixture of objectives for all three functions of IT in education. The Council considered it unrealistic to strive for goals in the coming years that focussed on 'learning through the use of IT.

The uncertainty about the next steps to take can slow the innovation process. Necessary expenditure to maintain the IT-infrastructure, like repairs and replacement, were not guaranteed to be covered. The financial framework of the action plan also did not take into consideration the new requirements that IT use imposed on the physical learning environment (housing, furniture, security).

The action plan envisaged establishing vanguard schools, which are ahead of other schools in the use of IT. This implies a widening of the gap between schools. The Council feels that the differences between schools due to the policy must be completely reversed. This could mean that a larger budget would have to be reserved for non-vanguard schools than for vanguard schools."

In the framework of this action plan 'Investing in Progress', primary and secondary schools were invited to submit project plans for the implementation of IT in education. A total of 119 vanguard schools were chosen which each produced a 
project plan. The plans were evaluated nationally and implemented in 1998. Again schools were supplied with PCs until there were 15 PCs per school. And teacher training was also organised. A review was published with the title 'Education Online, action in IT vanguard schools of secondary education'.

One important aspect of teaching and learning with the computer in the $21^{\text {st }}$ century is the appearance of digital teaching material, often in combination with a laptop, notebook or iPad or tablet for all pupils. Often publishers of schoolbooks provided digital teaching material and tests of the methods. Teachers were not very satisfied in general with this digital teaching material and wanted to develop their own. Research by Kennisnet (2010) and Zwaneveld and Rigter (2010) revealed that there was a lot to gain here. The quality of the teaching material that the teachers produced was not often good simply because they were not developers, and the support in the form of time off from teaching duties to develop such materials was too limited. The teachers' attempts to have this done as a group effort worked to the extent that materials were exchanged, but in general they preferred using their own material than what collectively was developed. Especially older teachers were noted to prefer keeping the familiar schoolbook.

In the period 2006-2010 a number of people, including the first author of this chapter, pressed the Minister of Education, Culture and Science to bring the subject of informatics into the $21^{\text {st }}$ century, especially since certain developments in that field, like the development of mobile technology - e.g. telephones and tablets, as well as social media - had no or at best a marginal place in the curriculum. This led to the Royal Netherlands Academy of Arts and Sciences setting up a commission in 2010 which produced a report in 2012 on 'digital literacy, skills and attitudes for the $21^{\text {st }}$ century'. This report paid a great deal of attention to learning with the computer. The subject of informatics was another focus. We cite here the beginning of the summary (Royal Netherlands Academy of Arts and Sciences 2012) and the first four recommendations:

"Digital literacy refers to the ability to make prudent use of digital information and communication and to evaluate the consequences of that use critically. In the $21^{\text {st }}$ century digital literacy belongs to the basic skills of every educated person. It is necessary for navigating one's way through the information society. Like language and mathematics skills, digital literacy requires instruction and education over a longer period of time. It should therefore be covered in our education system.

Recommendation 1

Introduce a new compulsory subject Information \& communication in the lower stage of havo and vwo. This should be a broad and compact introductory subject, covering the essential facts of digital literacy.

Recommendation 2

Completely overhaul the optional subject Informatics in the upper years of havo and vwo. By a flexible and modular design, the subject should remain up to date and appeal to pupils regardless of their focus area. 


\section{Recommendation 3}

Encourage interaction between these subjects and other school subjects.

\section{Recommendation 4}

Make a priority to raise a new generation of teachers with new skills and attitudes. Instruct the schools for higher professional education (hbo) and the universities to collaborate in this regard."

The report seemed to confirm the proposition that not much had changed in 2013 with regard to learning with and about computers since the 1980s: a lot was happening, but not enough, and certainly considering the rapid developments in IT and informatics.

\subsection{Information Science and Informatics}

At the end of the 1980s, teaching with and about computers - the school subject informatics - was being separated more and more. The first sign was the school subject of information science. Learning about computers became informatics, just like the discipline in tertiary education.

\subsubsection{Information Science}

The subject of information science merits a separate mention in this brief history. In this subject, the pupils were taught how to deal with computers. Originally, this was only word processing, the use of calculation programmes like spreadsheets and working with presentation programmes like PowerPoint. Later, after the arrival of the internet, searching, finding and processing of information were added.

In the 1980s information science was mandatory for the first three years of secondary education. But it was left up to the schools as to how they were to meet this obligation. Two models predominated. In the first one, information science was taught as a separate subject for one year (in year 1, 2 or 3). In the other model, parts of information science were integrated in the existing school subjects. For example, word processing was associated with Dutch, working with a spreadsheet with mathematics, and working with presentation programmes and searching, finding and processing information with practically every school subject. Since 2006 information science no longer exists as a school subject, but in the subjects Dutch and English, it was still included in the main goals (Government 2010): 'The pupil learns to use strategies to collect information from verbal and written texts.' And: 'The pupil learns to search in written and digital sources of information, arrange them and evaluate their worth for himself and other people.' It is assumed that the pupils have already mastered these skills before starting secondary education, that they acquired these skills at home. In general, this assumption has proven to be correct.

\subsubsection{Informatics}

Although it would take until 1998 before informatics became an official school subject, part of informatics, namely automatic data processing, had already been 
given a place in the second half of secondary education as a result of curriculum adjustment in mathematics (havo and vwo). In 1986 the subjects mathematics I and mathematics II (vwo) were replaced by mathematics A, which paid a great deal of attention to applications in economic problem situations in particular (algebra and statistics), and mathematics B which focussed more on pure mathematics (algebra, calculus, geometry) and on their application in the natural science subjects. In mathematics A the specified section 'automatic data processing' was incorporated. Pupils learned about algorithmic situations, for example, modelling statistics (to simulate probability experiments) using programme structure diagrams (psd). See Figure 1.

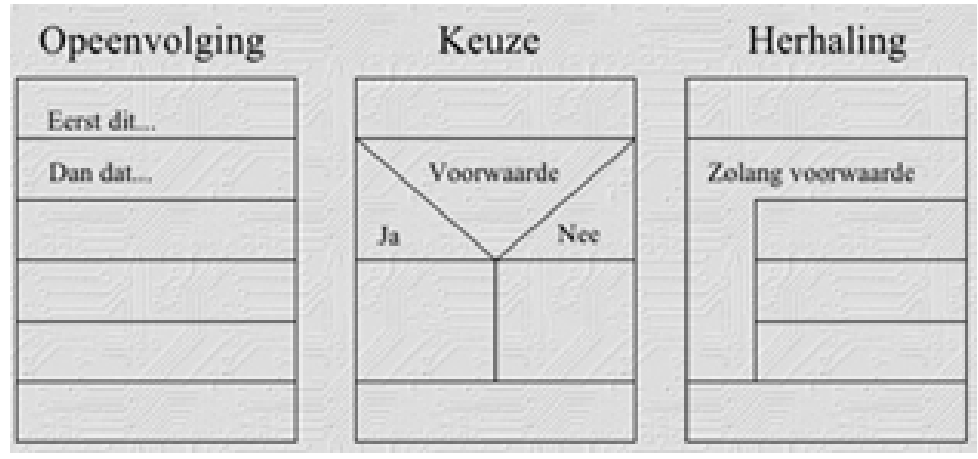

Fig. 1. The primary structures of a psd

For all vwo pupils mathematics was (and still is) a mandatory subject in the last two years. Many pupils choose mathematics A instead of mathematics B. This ensures that a relatively large number of pupils becomes acquainted with algorithms. At the next curriculum revision at the end of the 1990s, this section disappeared again.

As noted above, informatics only became a real school subject in 1998. Its aims are (Steering group Second Phase Profile for Secondary Education ${ }^{3}$ 1995):

"The Informatics course at the [...] secondary education level would be focused on providing students with:

- a view of Informatics and IT, and the relationship between these fields and other subject areas, as well as how they related to technology and society as a whole

- a picture of the role Informatics and IT would play in their education and career

- hands-on experience with Informatics and IT through:

\footnotetext{
${ }^{3}$ In 1993 the Second Phase Profile Steering Committee was established. (Instelling Stuurgroep Profiel Tweede Fase) (Instellingsbeschikking), in Uitleg Mededelingen OenW, no.18, 30 June 1993, 55-57). The Secondary Education Profile Act dates from 2 July 1997 (Stb. 1997-322). It defines four study profiles for havo and vwo: culture and society, economy and society, nature and health, nature and technology.
} 
- learning the basic concepts and skills of the subject

- studying Informatics problems

- studying the structures of data processing systems

o working on system development in groups

and all this within the context of how Informatics could be applied in society as a whole."

\subsection{Teacher Training}

Training teachers about learning with computers in the classroom deserves its own section. The following is partly borrowed from the Windesheim Magazine (1991).

\subsubsection{Training Trainee and Employed Teachers in the Use of Computers in Their Teaching}

As already stated, training teachers was part of the PRINT project, and courses were offered by universities of applied sciences, among other institutions. This was refresher training in the field of fundamental computer skills, system management in schools and informatics didactics for the school management.

From the beginning of the 1990s, computer-supported education was sometimes given in the teachers' training. This concerned IT use that aimed to help students acquire knowledge and skills, as was offered to students of other courses. From around 2000, all trainee teachers at many vocational colleges were offered ITmodules which aimed to prepare them for IT use in their future careers. This involved acquiring general IT skills, specific IT skills for teaching, like the use of a grading administration system and electronic learning environments, and specific IT skills for their subject. As soon as software/courseware became available, students were encouraged to use it during their practical training. Its limited availability at the training school was the most restrictive factor. The starting point of the education about the use of computers in the classroom was and is that computers are used in their own lessons and in the students' assignments with the vision: 'keep up to date and serve as an example for your students.' And 'IT-skillful teachers are found only where there are IT-skillful students'.

Since 2009 there is a knowledge basis of IT for teachers (Van der Linde 2009). This was developed at the initiative of Kennisnet for teachers in secondary education. This knowledge basis was used by the teachers' training aimed at teachers in the first half of secondary education. In 2013 a revision of this IT knowledge basis appeared (Bottema et al. 2013). In this revised version the aim of this knowledge basis was described:

"The IT knowledge basis describes the IT-competencies of newly qualified teachers and is thus an instrument that is used when setting end criteria in the curricula of the second-degree teachers' training (first few years of secondary education). A newly qualified teacher makes conscious and suitable use of IT in educational situations in which he makes the connection between subject-oriented learning goals, didactic forms and the employment of IT." 


\subsubsection{Training Trainee and Employed Teachers for Education in Informatics}

In the 1970s and 1980s there was no regular teachers' training in informatics, information science or IT. It was only from the end of the 1990s that vocational colleges offered teachers' training in IT, which led to sufficient competence for the first years of secondary education. Graduates could give lessons in the secondary (preparation) vocational education, and the training consisted of a mix of informatics subjects like programming and information analysis, and topics oriented more towards the management and maintenance of infrastructures and systems. For the prospective informatics teacher in all years of secondary education, universities have been offering since 2006 teachers' training at the level of a master of science.

The teachers' training courses have also contributed to the retraining of teachers from other subjects in IT and informatics. When a comprehensive increase of scale operation was imposed on secondary vocational education in 1991, a number of teachers was threatened with unemployment. These teachers were offered retraining in mathematics, economy and informatics. These retraining courses were also open to teachers from secondary education. The curriculum of the informatics retraining had a study load of 800 hours and consisted of subjects like information system development, programming, computer architecture, and informatics \& education. To prepare for the implementation of the informatics subject in the second phase of secondary education (havo/vwo) in 1998, an extensive retraining course was offered to teachers of other subjects in all years of secondary education. This course had a study load of 1260 hours and consisted of a broad range of informatics topics and informatics didactics. Around 300 teachers attended the course in three cohorts.

\subsection{Educational Teachers' Support}

Teachers are generally supported in their work by:

- courses

- books or periodicals

- educational software

- advisory bodies

- associations of teachers concerned with the content of education.

We give a summary of the first three at the end of this section. Unfortunately, we are not aware of the extent to which the supportive materials are actually used.

We shall consider first the relevant advisory body Kennisnet and the relevant teachers' association i\&i.

\subsubsection{Kennisnet}

For the support of all education in the use of IT, the expertise centre Kennisnet is the most important contributor. It was established at the end of the 1990s as part of the action plan 'Investing in Progress' (Minister of OCW 2001). On its website Kennisnet advertises itself as follows (Kennisnet 2013a):

"IT is interwoven in all aspects of society. IT is now commonplace in education also. The question is no longer whether IT will be employed, but in what manner. An integral approach to this is essential, and 
education recognises three domains. Along with the focus on IT in learning, the use of IT in the near future will be emphasised to increase the efficacy of the organisation and transparent justification. Kennisnet follows this development and acts as an IT-partner in these three domains.

Kennisnet facilitates the maximal use of the power of IT in all institutions in primary education, secondary education and secondary vocational education. We do this from three roles.

Kennisnet clarifies the characteristics of successful IT-applications and ensures that the knowledge, experiences and good examples are shared with education.

We create and manage the national IT-infrastructure that gives institutions freedom of choice and enables market parties to realise their own service provision.

We strive to inspire and offer a glimpse of the future by experimenting with new combinations of education and IT and sharing these insights.

By combining the available means in primary education, secondary education and secondary vocational education and coordinating and targeting their application, we can produce better and faster returns on the approximately 1 billion euros invested in IT by institutions."

\subsection{2 i\&i Association}

The teachers' association for informatics and IT is the i\&i Association. Originally, this was the abbreviation for information science and informatics, but with the establishment of the term IT and the abolition of the school subject information science, just the abbreviation i\&i came to be used. Its activities contribute to the development of a vision for IT in education. Its main activity is the annual national congress for members that includes IT co-ordinates who ensure that IT is properly used by teachers in school subjects, as well as the teachers of IT and informatics:

'The $i \& i$ Association welcomes all teachers who use IT in their lessons.

The association is an innovative community for teachers, education innovators, IT-coordinators and informatics teachers and wants to promote the expertise of its members and exchange knowledge in the field of didactics, teaching tools and technology. The didactics is the leading component. The association enables its members to become inspired for their daily work in education.

\section{Vision}

The $i \& i$ Association wants to promote the discussion of new educational concepts and is of the opinion that IT can act as a major stimulus and 
offer important facilities to realise these new concepts. The manner in which IT-resources are utilised in education is subject to change and is partly dependent on the teacher using them. In this dynamic world, $i \& i$ wants to play a prominent innovative role. Online and during the meetings organised by the association, the members encourage and inspire each other. Communal striving makes sense, responsible application of IT in education that prepares pupils for their role in a radically changing society. Through conferences, refresher training, inspiration sessions and various products, the association helps teachers to enrich their lessons with the use of IT in a responsible manner.

\section{Target groups}

The $i \& i$ Association focusses on the teachers and staff of primary/secondary education and secondary vocational education, education innovators, IT-coordinators, IT-managers, informatics teachers and anyone in whatever function who feels involved with IT in education.

\section{Interlocutor}

As an independent body, the $i \& i$ Association is an interlocutor for various organisations in the field of education and IT. In addition, $i \& i$ is the official partner of various university institutions regarding the content, status and perspective of the upper secondary school subject informatics. The association is also actively involved in setting up various new informatics courses."

\subsubsection{Courses}

We consider the first courses that teachers could take to be the teachers' training aimed at the early years of secondary education as part of the ' 100 -schools project' and the NIVO project. The course books developed for these teachers' training courses are used across the coutnry. The next one to mention is the European Computer Driving Licence, ECDL. The ECDL is an international certificate, it exists in 148 countries, including the Netherlands. The ECDL covers the basic computer skills. How many teachers have already obtained this computer driving licence is unknown. We do know it is the only course with an international end exam. Furthermore, the national pedagogic centres and the teachers' training focussing on the early years of secondary education offered (and still offer) courses in the field of education using computers. This support, primarily through courses and training, is currently conducted mostly by Kennisnet. For the school subject informatics, teachers can turn to the national science support centres. These centres, which are generally collaborations between universities and polytechnics, offer support to all teachers in the science and technology fields. 


\subsubsection{Books/Periodicals}

Regarding periodicals that supported (and still support) teachers in education using computers, the first one appeared in April 1983 and was called Computers at School. (Jan Lepeltak, mentioned earlier, was the chief editor of this periodical for a time.) It is still published ten times a year. We can confidently affirm that all aspects of education using computers have been addressed in this periodical.

At about the same time as NIOC1990, the periodical TINFON was issued which is especially oriented to informatics teachers. This timing was not a coincidence: the same people who initiated the NIOC did so on TINFON. TINFON, which stands for Periodical on Informatics Education, was the Dutch specialist periodical for education in informatics. It contributed to the professionalisation of informatics teachers and to the quality of informatics education. It contains articles about informatics education in secondary, tertiary, university, vocational education and company training. Along with articles about practical experiences with certain didactic approaches, attention was also paid to research into those approaches. In 2008 TINFON came to a premature end, unfortunately, due to too few subscriptions. Attempts to convert the periodical to a digital format have not yet succeeded.

Since1970 many books have appeared about learning with and about computers. In appendix B we provide a list that is certainly not comprehensive. We can characterise these books as follows. Most of them are meant for teachers (or other interested adults), there are just a few books for pupils, and they are mostly tied to mathematics. They almost always concern to a greater or lesser extent the architecture of computers and how they can be put to work by implementing a programme. Programming takes up a large part of the content. Applications are described, but only a few books support teachers in imagining how they are going to realise this in their classrooms, in terms of content, pedagogics or didactics. Details about books are given in appendix B.

\subsubsection{Software/Courseware}

The first software employed for education with computers was the packages provided as part of the NIVO project. This software was not used much because it was not standard software like Lotus 123, WordStar, WordPerfect, dBase, Office or their predecessors. Mention must be made of VU-Stat which was specially designed and developed for mathematics by someone in a teachers' training course in the 1980s to support the teaching of statistics, and that is still commonly used, in its updated form. Not only can this software deal with large data sets and carry out descriptive statistics on them, it can also do simulations and inductive statistical activities. We can also list for mathematics the computer algebra packages Derive, Maple, Matlab, and Mathematica. For the natural science subjects, we mention Coach that combines the processing of observations and scientific modelling on the computer. For informatics we cite programming languages like BASIC, Algol, Pascal.

In general, it can be ascertained that the quality of educative software/courseware was not that good, certainly in the beginning. In the special issue of Euclides, periodical for mathematics teachers, the teachers' trainer Nagtegaal (1983) covered in depth the development of educational software/courseware, and considered how that should be done professionally. He emphasised the quality of the software, referring 
specifically to the didactic quality. He claimed that the software supplied to schools as part of the 100-schools project left a lot to be desired. Furthermore, the teachers training institutes were involved in didactic refresher training of teachers of the subject information science from the mid-1980s.

\subsection{Students' Talent Development}

In this section we mention a memorable fact that is not history: the Informatics Olympiad. From 1989, following in the footsteps of subjects like mathematics and physics, the first international informatics competition was organised for talented pupils: the Informatics Olympiad. This competition consists of solving a number of rather complex programming problems in a relatively short period. The first Dutch entries date from 1990, when three pupils were sent to Minsk. A year later a national Dutch preliminary round was held, with the best participants going on to the international competition. Since then, the Netherlands has continued to send representatives each year to this international Informatics Olympiad. The Dutch participants often bring home medals and travel around half the world, except in 1995, when the international competition was held in the Netherlands itself.

\section{NIOC1990: A Turning Point}

As stated above, in 1984 De Bruijn remarked that - in our own words - there was little to no vision behind the government's plans with regard to the use of computers, and especially in education. The early adopters, the teachers who taught with and about computers from a very early stage, did have a vision about their use in education and in their own teaching. This vision can be formulated as follows: 'In the future it will be impossible to imagine life without computers. We have to prepare our pupils for this.' They did not know either how exactly to put this vision into practice sometimes teachers were convinced of this vision by parents who worked in automation or computerisation, see one of the stories in section 2, A few stories.

In 1990 the first serious attempt was made from the bottom-up to develop a communal vision on the use of computers in education. In that year the first National Informatics Education Congress, $\mathrm{NIOC}^{4}$, was held in Maastricht. Participants form the various relevant sectors, government-financed primary education, secondary education, vocational education and tertiary education, and the business sector with its company training, discussed for three days all aspects of education in IT and informatics in plenary lectures, parallel sessions, round tables, working groups, etc.

We consider NIOC1990 as a turning point in the education with and about computers. It is the first time that all involved educational sectors arrived at a communal vision. From the policy recommendations issued at the end of the congress, the assumption is evident that teaching with and about computers could be consolidated, as it was considered more or less self-evident. We cite here from the

\footnotetext{
${ }^{4}$ Since 1990 a NIOC is organised every two years.
} 
8-page document containing the recommendations the ones for general education (NIOC1990). For the sake of completeness, we state that far more happened at NIOC1990 than what we report here. We are restricting ourselves to secondary education.

"Policy recommendations for General Secondary Education

1. The government should take decisions and provide guidance to schools and institutions on the basis of the vision produced herein about the manner in which the subject of informatics/information science should be incorporated in secondary education. If no decisions are taken, the achievements and investments made so far will be lost. For adult education modified decisions should be taken.

2. The guidance should consist of:

a) Programming the role of the institutions doing the teaching;

b) Promoting the development of educative software;

c) Providing content for the subject of informatics at the school level as in the final objectives recommendations for the basic curriculum and the PRINT-recommendation for the second phase;

d) Establishing a learning continuity pathway;

e) Earmarking resources and facilities for schools.

3. Better regulations must be created for the competence to teach informatics. The institutions must respond in turn by offering possibilities to obtain a specific, well defined level of competence.

4. Schools must develop a strategy for the creation of the subject of informatics. The school management must take responsibility for the coordination and necessary means and facilities.

5. The educational support institutions should intensify activities aimed at informatics education: curriculum and test development, research and implementation."

There is a certain consolidation of computers in education that has become apparent since NIOC1990 as the government is increasingly reducing financial resources, and is taking a less regulatory stance in its policy.

In the meantime from the didactic viewpoint, visions are being developed for the use of computers in education. Kennisnet (2013b, p. 5) formulates this as follows:

"Dutch education is bursting with ambition. Excellent education, given

by professional teachers in purposefully equipped schools. Education that matches the talents, skills and learning style of each pupil. Education that nurtures the best in each pupil. This is needed desperately. Society is changing at a rapid pace. The education must move with this change and the skills and talents needed in the $21^{\text {st }}$ century. This ambition cannot be realised without a proper employment of IT. If IT is used in the correct manner, this will lead to greater motivation, better learning performances and a more efficient learning process for the pupil. It can also help the teacher to professionalise 
themselves. In addition, IT can lead to a better organisation in school with greater transparency and better guidance."

This statement by Kennisnet is supported by many others. The president of the Royal Netherlands Academy of Arts and Science, Hans Clevers, formulated part of the vision on learning with and about computers in the form of several questions referring to the skills and attitudes (Royal Netherlands Academy of Arts and Science 2013 , p. 5) on a very tangible level.

"Is the first search result in Google the best one? How reliable is the information found? May I simply use all of the information on the internet? Who can see my profile on the internet and what are the associated risks?"

And we would like to add our vision to this: "Citizens should be capable on the basis of their knowledge of IT and their good experiences with its use to help give direction to new developments in the field of IT.'

\section{Conclusions}

The history of learning with and about computers in the Netherlands in the past period of over 40 years, as described above, leads us to the following two conclusions.

At the very beginning, in the 1970s, there was no distinction between the use of the computer as a tool and informatics. The first teachers who realised the importance of computers for society and thus for education, had to program their computer using informatics. This limited the use of computers in the classroom. The advances in technology and the tendency to make computers more user-friendly allowed a growing distinction to be made between informatics on the one hand and what we now call IT on the other. Nevertheless, it took until the end of the 1990s before informatics was introduced as an independent school subject in secondary education. Furthermore, the attention paid to fundamental computer skills, was ultimately given shape in the school subject information science, but has been almost completely marginalised since then. This is also related to the increasing technological developments and greater ease of use. This progress in the possibilities of the computer, the increasing availability of educational software and the attention paid in teachers' training to teaching with the computer led to a certain consolidation of the use of computers in school subjects from the beginning of the 1990s.

Government policy also made an important contribution to this consolidation. Initially, computers were used in education only at the initiative of individual teachers, but in the 1980s and early 1990s, the government took action by stimulating computers in education with funds for equipment, software, training and other support. The government expected to achieve the desired consolidation much earlier, but again and again it proved necessary for the government to initiate new projects. Since the mid-1990s no new projects have been started by the government.

With some exaggeration, the government's policy can be characterised as lagging a bit behind the initiatives of individual teachers. The initiatives aroused the government. It then took the lead for what it hoped would be only a short time, 
ultimately turning it over to the educational field. This then turned out to be an underestimate, and as a result, the government had to become active again. That still applies today, as it seems that the digital world of the $21^{\text {st }}$ century again has a need for a government initiative, for learning both with and about computers. We repeat here once again recommendation no. 1 of the Royal Netherlands Academy of Arts and Science (2012):

"Introduce a new compulsory subject Information \& communication in the lower years of havo and vwo. This should be a broad and compact introductory subject, covering the essential facts of digital literacy."

Acknowledgements. We thank Jan Timmers, Willem van der Vegt and Ton Konings for their valuable additions and improvement of earlier versions of this chapter. Further, we thank especially the teachers who participated during the NIOC2013 in the relevant session. In the person of Hans Frederik we thank the NIOC-board for the financial contribution to the production of this chapter.

\section{References}

Bottema, J., Erkelens, N., van der Hoeff, A., van der Linde-Koomen, D., Schols, M., TollenaarHartogensis, A., Bos-Wierda, R., Barendsen, R.: Kennisbasis IT 2013. Algemeen Directeurenoverleg Educatieve Faculteiten (2013)

Casimir, C.: In-service Training in the NIVO-project in The Netherlands. European Journal of Education 23(4), 315-321 (1988)

De Bruijn, N.G.: Het Informatica-Stimulerings Plan. Informatie en Informatie beleid, 5 (1984)

Docters van Leeuwen, R.: Lesgeven met computers. Onderwijskundige aspecten van educatief computergebruik, vol. 2. NIB, Zeist (1982)

Euwe, M.: Deel uit de toespraak bij de opening van de V.U.-tentoonstelling over informatica bij gelegenheid van net 100 jaar bestaan van de V.U. Euclides 55(10), 441 (1980)

i\&i (2013), http: / / ieni .org / over-ieni / (retrieved July 2013)

Kennisnet. Vier in Balans Monitor 2009. Kennisnet, Zoetermeer (2010)

Kennisnet. Kennisnet: over ons (2013a), http://www.Kennisnet.nl/over-ons / (retrieved October 2013)

Kennisnet. Vier in balans monitor 2013, De laatste stand van zaken van IT en onderwijs. Kennisnet, Zoetermeer (2013b)

Koninklijke Akademie van Wetenschappen. Digitale geletterdheid, vaardigheden en attitudes voor de 21ste eeuw, pp. 10-11. Koninklijke Akademie van Wetenschappen, Amsterdam (2012)

Lepeltak, J.: Nederland investeert in sprong vooruit, Educatie moet bijdragen aan de ontwikkeling van 'main port' naar 'brain port' Computable (April 4, 1997), http: / /www. computable.nl/artikel/achtergrond/education/ 1391848/1277214/nederland-investeert-in-sprong-vooruit.html (retrieved October 2013)

Van der Linde, D., Van der Hoeff, A., Pronk, H., Van Ast, M.: Kennisbasis IT. Algemeen Directeurenoverleg Educatieve Faculteiten (2009)

Ministeries van Onderwijs en wetenschappen. van Economische zaken en van Landbouw en Visserij. Informatica-Stimuleringsplan, Beleidsvoornemens tot bevordering van informatica en informatietechnologie in Nederland. Ministerie van O and W., Zoetermeer (1984) 
Ministeries van Onderwijs en wetenschappen. van Economische zaken en van Landbouw en Visserij. Onderwijsappendix bij het Informatica-Stimuleringsplan, Versnelde invoering van informatietechnologie in het onderwijs. Ministerie van Onderwijs en wetenschappen, Zoetermeer (1984)

Ministerie van Onderwijs en wetenschappen. Nieuwe informatietechnologie in het voortgezet onderwijs, brief van de staatssecretaris van onderwijs en wetenschappen aan de Voorzitter van de Second Kamer der Staten-Generaal. Ministerie van Onderwijs en wetenschappen, Den Haag (1990)

Ministerie van Onderwijs en wetenschappen. Enter: de toekomst. SDU, Den Haag (1992)

Minister van Onderwijs, cultuur en wetenschappen. Onderwijs on line, actualisatie. Ministerie van Onderwijs, cultuur en wetenschappen, Den Haag (2001),

http: / / www.rijksgovernment.nl/bestanden/.. / education-on-line. . / actualisatie.pdf (retrieved October 2013)

Nagtegaal, C.: De invloed van Bergen op de kwalieit van onderwijs-software. Euclides 59(2) (1983)

NIOC (1990), http: / / nioc.nl/nioc/1990/docs /

NIOC1990_policysrecommendations .pdf (retrieved July 2013)

Advisory Council for Education. Advies over Informatie- and Communicatie Technologie and Onderwijs, uitgebracht aan de Minister van Onderwijs, Cultuur and Wetenschappen. Adviesraad voor Onderwijs, Den Haag (1998)

Rijksoverheid. Kerndoelen. Rijksgovernment, Den Haag (2010),

http: //www.rijksgovernment.nl/

documenten-en-publicaties/besluiten/2010/09/17/kerndoelenonderbouw-secondary-education. html (retrieved October 2013)

Stuurgroep Profiel Tweede Fase Voortgezet Onderwijs. Verschil moet er zijn. Stuurgroep Profiel Tweede Fase Voortgezet Onderwijs, Den Haag (1995)

Ten Brummelhuis, A., Plomp, T.: Lessons from Two Dutch Projects for the Introduction of Computers in Schools. Computers in Education 20(4), 333-340 (1993)

Ten Brummelhuis, A., Plomp, T.: Computers in Primary and Secondary Education: The Interest of an Individual Teacher or a School Policy? Computers in Education 22(4), 291-299 (1993)

Ten Brummelhuis, A., Plomp, T.: Informatietechnologie in het onderwijs: vijftien jaar beleid. De stand van zaken na 15 jaar overheidsstimulering op het gebied van informatietechnologie in het onderwijs: eindpunt of tussenstation? Adviesraad voor Onderwijs, Utrecht (1994)

Windesheim Magazine: Kuper, D.: Computer ondersteuning in onderwijs; van der Vegt, W.: Teachers opleiden in informatica; van der Vegt, W.: Retraining tot teacher informatica. Windesheim, Zwolle (1991)

Zwaneveld, B., Rigter, H.: Over drempels naar meer IT-gebruik in het voortgezet onderwijs, Rapport naar aanleiding van het project DigilessenVO in 2009. Open Universiteit, Heerlen (2010) 


\section{Appendix A: Examples of Early Computer Programmes about Learning with the Computer}

Examples of courseware with which the pupils can work independently (referrals to sections of the book have been deleted):

\begin{tabular}{lllll}
\hline no. & name & didactical use & specialism & computer type \\
\hline 1 & PH-exercise & Drill \& practice & chemistry & BASICODE \\
2 & Water pollution & Simulation & biology/geography & PET/CBM \\
3 & Verb forms1 & Tutorial & Dutch & PET/CBM \\
4 & Verb forms2 & Tutorial & Dutch & BASICODE \\
5 & Long division & Tutorial & mathematics & PET/CBM \\
6 & Decimal division & Tutorial & Mathematics & PET/CBM \\
7 & Fractions & Application & mathematics & BASICODE \\
8 & Basic & Tutorial & informatics & PET/CBM \\
9 & Alphabet & Application & informatics & BASICODE \\
10 & Racing cars & Simulation & physics & BASICODE \\
11 & Decision-making & Application & social sciences & BASICODE \\
12 & Search_for the_word & Drill \& practice & Dutch & BASICODE \\
13 & Reduction & Application & mathematics & BASICODE \\
14 & Predator/prey & Simulation & biology & BASICODE \\
15 & Haiku & Application/AI & Foreign languages & BASICODE \\
16 & Othello & Game & general & BASICODE \\
17 & Titration & Simulation & chemistry & PET/CBM \\
18 & Water management & Simulation & social sciences & PET/CBM \\
19 & Ladder game & Game & general & PET/CBM \\
20 & Printsit & Application & informatics & PET/CBM \\
21 & Planetarium & Simulation/application & physics & PET/CBM \\
22 & Chemparser & Application & Chemistry/language & BASICODE \\
23 & Galton board & Simulation & mathematics & PET/CBM \\
24 & Titration curves & Simulation & chemistry & PET/CBM \\
25 & Black box & Simulation & natural sciences & PET/CBM \\
26 & Times tables & Drill \& practice & mathematics & BASICODE \\
27 & Rectangles & Tutorial & mathematics & CBM \\
28 & VAA-system & Real-time application & didactics & PET2001 \\
\hline & & & &
\end{tabular}

\section{Appendix B: A Bibliography about Learning with and about the Computer}

In this appendix we present the books chronologically. Their content is described briefly in italic fond. The books aim at teachers and in some cases also at pupils. If so, it is specified.

M. Euwe (1966). Inleiding tot computer en automatisering. Alphen aan de Rijn: Samsom BV. This book is about two aspects: computers, how they work and how one can program it and about the automation which is enabled by the computer. 
W.J. Muhring \& H.A.A. van Dorenmalen (1970) Automatisering, oriëntatie op het gebied van informatieverwerking. Groningen: Wolters-Noordhoff. Met een voorwoord van Prof. Dr. M. Euwe. After a description of a computer and how it works and can be programed, the book provides a number of applications. It offers mainly background information for teachers.

C. Görts, S. v.d. Meulen, A. v.d. Sluis, \& J. Zweerus, (1972). Computerkunde 1 en 2 voor a.v.o en v.w.o. Groningen Wolters-Noordhoff. This book offers the students, after a short introduction to computers, an almost complete course ECOL (see the text in the frame on page $x$ ) and a very large number of examples of projects to the students.

W. van den Camp, H. Emanuels, J. Lubke, \& P. Ploeger, (1971/1972). Elementaire computerkunde, Deel 1voor mavo en havo; Deel 2voor mavo, havo en vwo. Amsterdam: Meulenhoff Educatief. These two books aim at students. They give an impression how computers work and how they can perform tasks by use of a programming language, here a part of ALGOL.

R.P. van de Riet (1980) Computer \& Beroep. Amsterdam: Vrije University. About an exhibition at the hundredth anniversary of the Vrije Universiteit.

B. Camstra (1980). Leren en onderwijzen met de computer. Leiden: Stenfert Kroese. The book offers the most important knowledge about computer assisted instruction to potential users of computers in education (and to them who are against it).

Chr. De Boer \& P. Pottjegort, (1981). Computersystemen, de computer en zijn gebruiker. Alphen aan de Rijn: Zorn Uitgeverij BV. This book describes rather completely technical aspects of the computer. There is also a chapter about applications and about business systems. There is little attention for the role of the user of the computer.

W.GE. Wouters (1981). De programmeertaal BASIC. Zutphen: Thieme. This book is written in order to teach students to program in BASIC.

W.P. Janssen (no year of publishing). Onderwijs en computer. Amphi-reeks. Den Bosch: Malmberg. This book discuss subjects like how the computer works, how to deal with the computer, didactics of the teaching with the computer, educational software, information technology.

D. Dijkstra \& S. Metselaar (1982). Voor het eerst ... beginnen met de computer. Groningen: Wolters-Noordhoff. This book is no more than an introduction into BASIC.

J. Schoenmaker, W. van Zundert, \& J. Engelen (1982). Informatica met de microcomputer. Den Bosch: Malmberg. This book offers an introduction into what computers are and in programming in BASIC, but also how to apply the computer in other school subjects like mathematics, physics and economy.

R. van Dongen en R. Docters van Leeuwen (1982). Lesgeven met computers 1, het ontwikkelen van lespakketen. Zeist: NIB. This book offers a lot of support to the reader who wishes to design and develop educational software.

R. Docters van Leeuwen (1982). Lesgeven met computers 2, onderwijskundige aspecten van educatief computergebruik. Zeist: NIB. As a sequel to the fore mentioned book, this book is especially about the didactical and pedagogical aspects of the use of computers in education. 
Chr. De Boer, (1983). Computerlexicon: Educaboek. Exactly what the title says: an elaborate lexicon of all terms used at computers.

U. de Jong \& F. van der Heijden (1983). Computerwerk. Den Bosch: Malmberg. On the basis of about ten applications the students learn to perform tasks with BASIC.

\section{Appendix C: Educational System of the Netherlands}

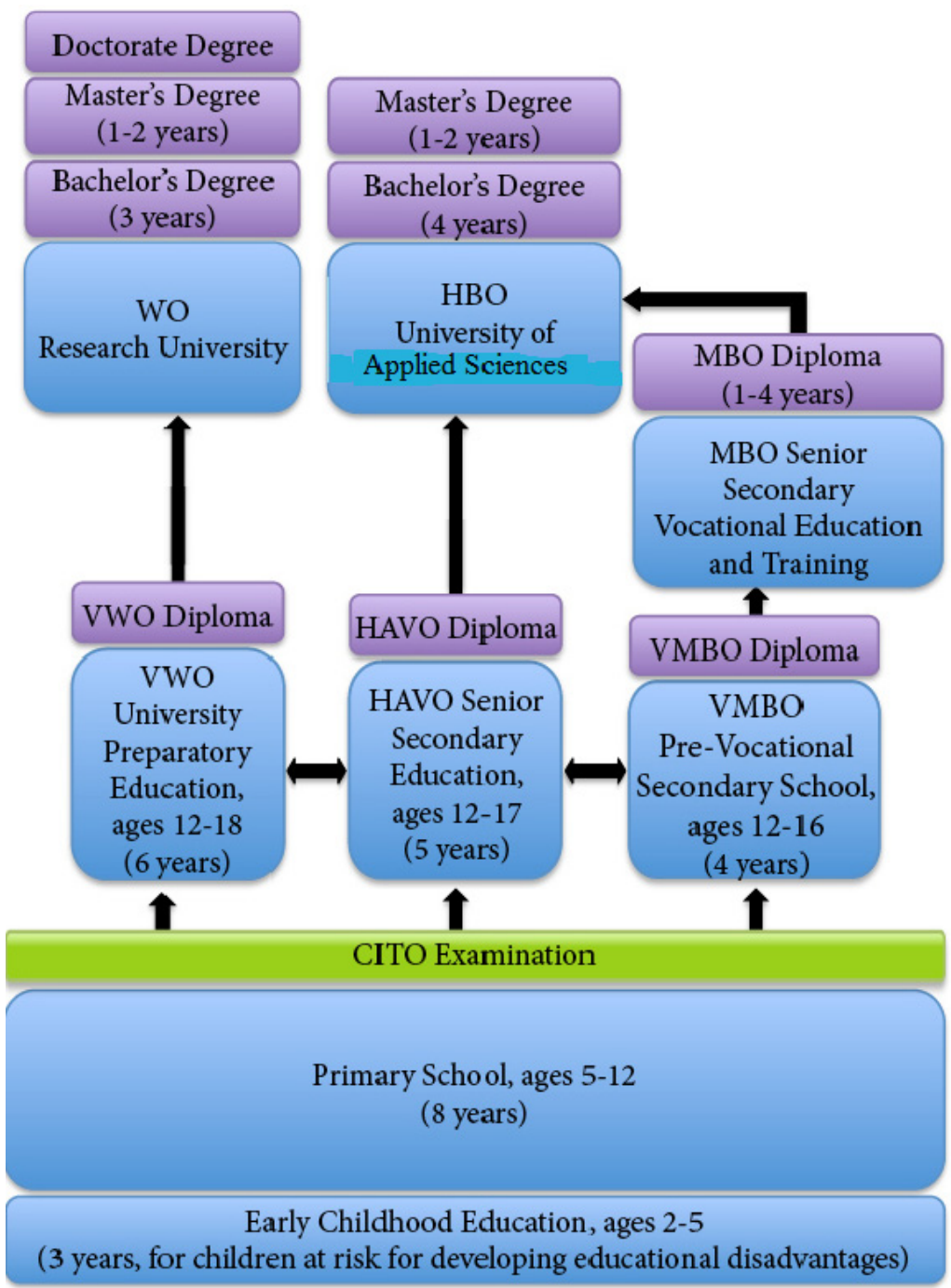

